\title{
ФОРМУВАННЯ ОБРАЗУ ЛІДЕРА НАЦІЇ ЗАСОБАМИ МЕТАФОРИ У ПРОМОВАХ КАНЦЛЕРКИ АНГЕЛИ МЕРКЕЛЬ
}

Стаття розглядає особливості формування образу лідера в промовах Ангели Меркель засобами метафори. Метафора аналізується не просто як засіб образності, а як спосіб аргументації $і$ концептуального впливу на громадян, як ментальна операчія з надпотужним прагматичним потенціал у способі формування й описі картини світу.

Дані кількісного аналізу досліджуваного матеріалу засвідчують, щзо в більшості промов домінують метафори з понятійними сферами людини та соиіуму. У випадку зі сферою людини мовцем моделюється картина світу у спосіб, шчо максимально наближує властиві людській діяльності поняття, як-от емоиійно-чуттєве сприйняття дійсності, життя та смерть, просторові та часові орієнтири, дім. Метафори саме иього типу сприяють ефективному конструюванню позитивних і негативних аксіологічних моделей інтерпретації картини світу адресатом.

Невід’'смним атрибутом виступів Ангели Меркель, особливо коли йдеться про важливі проблеми, війни, епідемї, є метафори емочійно-чуттєвого сприйняття людини. Семантика прикметникових вкраплень ініціальної частини висловлювання у поєднанні з негативним аксіологічним потенціалом самої метафори створює експланаторну тональність, яка, зрештою, дає змогу пом'якиити можливе негативне сприйняття рішень. Примітною в контексті иьього є метафори зі сфери катаклізмів, труднощів і викликів, тому шуо вони формують у свідомості слухача низку образів із негативним конотативним забарвленням. При розгортанні текстового фрагмента ие виконує роль контрастуючого елемента, який протиставляється рішучості канилерки, ї̈ здатності виявляти характер лідера за складних обставин.

Здійснений аналіз дає змогу констатувати, щчо засобами метафори Ангелою Меркель конструюється і позитивно, і негативно аксіологічні моделі інтерпретації картини світу. При изьому обидві моделі однаково вагомі для формування образу лідера, оскільки вони насамперед створюють певне уявлення про ситуачію, в контексті якоі підкреслюються здобутки діяльності канилерки. Найбільи продуктивними метафорами є такі понятійні сфери, як сочіум і людина. Саме їхнє функціонування дає змогу описувати заходи для подолання економічних викликів $i$ збільшувати ефективність власної політичної поведінки.

Ключові слова: метафора, сфера-джерело, промова канилера, образ лідера.

Nataliia MARCHENKO, orcid.org /0000-0003-2531-3153

Senior Lecturer at the Department of Foreign Philology,

Translation and Teaching Methodology

Hryhoriy Skovoroda University in Pereyaslav

(Pereyaslav, Kyiv region, Ukraine) 1marchenko_n@ukr.net

\section{THE NATION'S LEADER IMAGE FORMATION BY MEANS OF METAPHORS IN THE SPEECHES OF CHANCELLOR ANGELA MERKEL}

The article studies the peculiarities of the leadership image formation by means of metaphor in Angela Merkel's speeches. Metaphor is analyzed not only as a figure of speech, but also as a means of argumentation and conceptual influence on citizens, as a mental operation with a powerful pragmatic potential to form and describe the picture of the world.

Our quantitative analysis data of the material show that the metaphors with the conceptual spheres HUMAN and SOCIETY predominate in the vast majority of speeches. In case of the sphere HUMAN, the speaker simulates the picture of the world by exposing the concepts relevant to such human activities as emotional and sensory perception of reality, life and death, spatial and temporal points, and home. These are the very metaphors that contribute to the effective construction of positive and negative axiological models in the addressee's interpretation of the picture of the world.

A common feature of Angela Merkel's speeches, especially when she speaks on important problems, wars, and epidemics, is metaphors of human emotional and sensory perception. The semantics of adjectives in the initial part of the utterance in combination with the negative axiological potential of the metaphor itself create an explanatory tone, which 
eventually allows mitigating a possible negative perception of the chancellor's decisions. Another important feature is the metaphors of cataclysms, difficulties and challenges, and the way they make the listener conjure up a number of images with negative connotations. While the speech is being delivered, they function as contrasting elements, which highlight the Chancellor's determination, her ability to reveal the character of a leader under difficult circumstances.

The analysis allows us to state that by means of metaphor Angela Merkel constructs both positive and negative axiological models for interpretation of the picture of the world. At the same time, both models are equally important for the leadership image formation because they create a certain idea of the situation in the context of which the achievements of the Chancellor are emphasized. The most productive metaphors are such conceptual spheres as society and human. It is their wide use that allows the Chancellor to describe measures to overcome economical challenges and increase the effectiveness of her own political behavior.

Key words: metaphor, sphere-source, chancellor's speech, image of leader.

Постановка проблеми. Образність, створювана метафорично опосередкованими мовними одиницями, не лише здатна підвищити виразність будь-якого мовленнєвого акту, але й бути чи не найдієвішим засобом формування власного образу в процесі взаємодії з іншими представниками суспільства. Особливої значущості подібні процеси набувають у ситуації, де діяльність й успішність мовця залежать від вдало дібраних мовних засобів. Мовлення відомої жінки-політика Німеччини, яка півтора десятиліття обіймає відповідальну посаду, вміло поєднуючи здатність приймати важливі рішення і доносити свою позицію майорить різними формами та прийомами. Проте жвавості та експресивності воно набуває часто завдяки саме вдало створюваним метафорами образами, які залишають тривалий відбиток у свідомості співвітчизників.

Аналіз досліджень. Політичний дискурс $\epsilon$ об'єктом досліджень багатьох науковців, як українських, так і зарубіжних, зокрема К. С. Гаджієва, О. В. Падалки, К. Б. Цветкової, О. Й. Шейгал. О. М. Тищенко, А. О. Худолій, В. Є. Чернявська та А. П. Чудінов, займалися дослідженням особливостей систем концептуальних метафор у промовах політиків. Ch. Scheuerle, M. Schröter, M. Nölke досліджували стратегії політичної комунікації та особливості мовної особистості політиків.

Риторична діяльність німецькомовної канцлерки характеризується значним масивом стилістичних засобів образності, про що свідчить велика частка досліджень, присвячених саме цьому питанню (Цаголова, 2014; Тамерьян, 2019; Neubrand, 2009). Подібне цілком закономірно, оскільки функціонування таких засобів наділяє промови будь-якої тематичної спрямованості додатковою емоційністю, а отже, є ефективним прийомом захоплення та утримування уваги аудиторії. При цьому вважається, що саме формування багатошарової структури образу політика досягається, передовсім, концептами 3 метафоричним лексико-семантичним шаром в основі (Тамерьян, 2019: 141).
3 огляду на роль метафори як засобу аргументації і концептуального впливу на громадян, іiі надпотужний прагматичний потенціал у способі формування й описі картини світу, здатної бути і контейнером столітнього досвіду, і ретранслятором специфічних стереотипів певної етнокультури, важливим $\epsilon$ аналіз особливостей та способів формування образу лідера.

Метою статті - проаналізувати особливості способів формування образу лідера засобами метафори в промовах канцлерки Ангели Меркель.

Матеріалом дослідження слугували виступи А. Меркель впродовж періоду канцлерства з 2018 по 2020 рр., у процесі якого було відібрано 107 висловлень із метафорами. Як методологічний базис дослідження застосовано такі методи: метод суцільної вибірки, класифікаційний метод, концептуальний аналіз, статистичний метод.

Виклад основного матеріалу. У нашому дослідженні ми виходимо, по-перше, 3 розуміння Ангели Меркель як харизматичного політика 3 високими управлінськими якостями, що забезпечили іiі тривалу та ефективну політичну діяльність. По-друге, враховуємо також думку В. Савчука про самопрезентаційність як пропозиційний базис виступу будь-якого професійного політика, крізь призму чого, незважаючи на тематику та обставини, підкреслюються досягнення, зобов'язання, перспективи і таке інше. Тобто увесь комплекс вербальних і позавербальних засобів спрямовано на формування, зміну чи збереження власного образу (або іміджу) (Савчук, 2017: 148). Подібне можна спостерігаємо у такому прикладі: Wir tun alles, damit unsere solidarische soziale Marktwirtschaft sich in dieser Prüfung bewährt (Mu робимо все для того, щчоб наша соиіальна ринкова економіка, заснована на солідарності, виправдала себе в цьому іспиті) (Merkel, 2020 (7)).

Аналіз наведеного фрагменту дає змогу пересвідчитися у його загальній інтеціональній спрямованості - представити себе та свою ефективність, що особливо сильно експліковано в ініціальному відрізку, зокрема при слуховому 
Марченко Н. Формування образу мілера нації засобами метафори ...

сприйнятті промови. Проте кульмінаційним фрагментом варто вважати саме кінцевий відрізок із метафорою, яка і підсилює загальну семантику висловлення, й імпліцитно формує образ рішучого менеджера.

Власне проаналізований нами матеріал дозволив і переконатися у правомірності подібних суджень і здійснити класифікацію метафор відповідно до трьох наведених у Таблиці 1 понятійних сферджерел: 1) соціум; 2) людина; 3) система цінностей. Зазначені сфери-джерела сприяють формуванню достатньо широкої палітри метафоричних моделей, які своєю чергою забезпечують ефективні шляхи конструювання картини світу слухачів (табл. 1).

Конструктами соціально зумовлених метафор $\epsilon$ такі понятійні сфери, як боротьба, відповідальність, законопорушення, досягнення, катаклізми / труднощі / виклики.

Аналіз матеріалу дав змогу з'ясувати, що основу значної частки метафор становить боротьба $13,7 \%$. Ця особливість пояснюється потребою політика акцентувати на мінливих реаліях сьогодення, де їй доводиться вирішувати чисельні труднощі. Уміле поєднання постійної боротьби та потреби досягати нових звершень у різноманітних сферах сприяе формуванню віри аудиторії у виняткову роль мовця в цьому процесі. Наприклад: Wir wissen ja, dass wir uns weltweit in einem ständigen Wettbewerb um die besten Ideen und Innovationen bewegen (Ми ж знаємо, шоо ми перебуваємо в постійному світовому змаганні за найкращі ідеї та інноваиіi) (Merkel, 2020 (7)). Як бачимо, вступна частина розкриває свідомість слухача фразою Wir wissen ja, формуючи уявлення про подальшу тезу як загальновідомий факт, тоді як морфологічний повтор у формі займенника першої особи множини закладає підвалини єднання 3 мовцем. Власне інтерпретація діяльності політика представлена як єдине та спільне змагання усієї нації за передові технології.

Особливого виділення такі фрагменти досягають саме завдяки функціонуванню метафор із понятійною базою різних аспектів соціаль-

Метафоричні репрезентанти образу лідера А. Меркель

Таблиця 1

\begin{tabular}{|c|c|c|c|}
\hline $\begin{array}{c}\text { Понятійна } \\
\text { сфера-джерело }\end{array}$ & $\begin{array}{c}\text { Різновид } \\
\text { метафори }\end{array}$ & $\begin{array}{c}\text { Частка } \\
(\%)\end{array}$ & Види метафори (приклад [за джерелом]) \\
\hline \multirow{5}{*}{ СОЦІУМ } & Боротьба & 13,7 & $\begin{array}{l}\text { БОРОТЬБА - ЦЕ ТВОРИТИ ДОЛЮ ВЛАСНОРУЧ (unser } \\
\text { Schicksal in die eigene Hand nehmen (Merkel, } 2020 \text { (9)); die } \\
\text { Erfoge nicht vom Himmel fallen (Merkel, } 2018 \text { (6)); } \\
\text { ШЛЯХ РОЗВИТКУ - ЦЕ ПОСТІЙНЕ ЗМАГАННЯ (in einem } \\
\text { ständigen Wettbewerb um die besten Ideen und Innovationen } \\
\text { bewegen (Merkel, } 2020 \text { (7)); Wie bekommen wir globale Champi- } \\
\text { ons auch in Europa? (Merkel, } 2020 \text { (8)). }\end{array}$ \\
\hline & Законопорушення & 11,7 & $\begin{array}{l}\text { НЕПРАВОМІРН ДІЇ - ЦЕ ЗАХОПЛЕННЯ ДЕМОКРАТІЇ } \\
\text { ГБРИДНИМИ МЕТОДАМИ (greift westliche Demokratien mit } \\
\text { hybriden Mitteln an (Mеrkel, } 2020 \text { (9)); } \\
\text { НЕПРАВОМІРНІ ДІЇ - ЦЕ ЗАТЯГНУТИ РЕМІНЬ НЕВИ- } \\
\text { РІШЕНОМУ КОНФЛКТУ (einen Gürtel ungelöster Konflikte } \\
\text { geschaffen (Merkel, 2020 (8)); } \\
\text { ПЕРЕПОНИ РОЗВИТКУ - ЦЕ ПОСТАВИТИ НА КАРТУ } \\
\text { ЧИЙСЬ ДОБРОБУТ (aufs Spiel setzen (Merkel, 2020 (8)); (Es } \\
\text { gibt eine Reihe schwelender Handelsstreitigkeiten (Merkel, } 2020 \\
\text { (8)). }\end{array}$ \\
\hline & $\begin{array}{l}\text { Катаклізми, труд- } \\
\text { нощі, виклики }\end{array}$ & 8,6 & $\begin{array}{l}\text { ЗІШТОВХНУТИСЯ З ТРУДНОЩАМИ - ЦЕ ОПИНИТИСЯ } \\
\text { У ГЛУХОМУ КУТІ (in einer Sackgasse stranden (Merkel, } 2020 \\
\text { (8)); } \\
\text { ПОДОЛАННЯ КРИЗИ - ЦЕ РОЗРИВАННЯ ЛАНЦЮЖКА } \\
\text { (zur Unterbrechung der Infektionsketten (Merkel, } 2020 \text { (8)); } \\
\text { ТРУДНОЩІ - ЦЕ ВИМОГА ДЛЯ ДЕМОКРАТІЇ (dieses Virus } \\
\text { ist und bleibt eine demokratische Zumutung (Merkel, } 2020 \text { (9)). }\end{array}$ \\
\hline & Досягнення & 5,4 & $\begin{array}{l}\text { БУТИ УСПІШНИМИ - ЦЕ ПОКАЗУВАТИ СЕБЕ (Unser Land } \\
\text { zeigt sich (Merkel, } 2020 \text { (7)) }\end{array}$ \\
\hline & Відповідальність & 7,4 & $\begin{array}{l}\text { ЕФЕКТИВНА ДІЯЛЬНІСТЬ - ЦЕ ВІДЧУТТЯ ВІДПОВІ- } \\
\text { ДАЛЬНОСТІ ЗА ВСЮ СВРОПУ (...nimmt das Land eine große } \\
\text { Verantwortung für ganz Europa wahr (Merkel, } 2020 \text { (8)); } \\
\text { ЕФЕКТИВНА ДІЯЛЬНІСТЬ - ЦЕ ВЗЯТИ НА СЕБЕ ВІДПО- } \\
\text { ВІДАЛЬНІСТЬ ЗА БЕЗПЕКУ (die Verantwortung für Frieden } \\
\text { und Sicherheit in der Welt übernimmt (Merkel, } 2020 \text { (9)). }\end{array}$ \\
\hline
\end{tabular}


Продовження таблиці 1

\begin{tabular}{|c|c|c|c|}
\hline \multirow{4}{*}{ ЛЮДИНА } & $\begin{array}{l}\text { Емоційно-чуттєві } \\
\text { сприйняття }\end{array}$ & 7,4 & \begin{tabular}{|l|} 
СЛІДУВАТИ КУРСУ - ЦЕ РОЗБУДИТИ НАДІЇ (Hoffnungen \\
wecken würden (Merkel, 2020 (7)); \\
ДІЯТИ - ЦЕ ТРИМАТИ В ПОЛІ ЗОРУ (wenn wir uns vor Augen \\
führen (Merkel, 2020 (7)); Im Blick behalten (Merkel, 2020 (8)); \\
über den eigenen Tellerrand zu schauen (Merkel, 2019 (10))
\end{tabular} \\
\hline & Життя та смерть & 6,3 & $\begin{array}{l}\text { ЕФЕКТИВНА ДІЯЛЬНІСТЬ - ЦЕ ОЖИВИТИ ІНІЦІАТИВУ } \\
\text { (die Initiative... ins Leben gerufen haben (Merkel, 2019 (11)); } \\
\text { ЕФЕКТИВНА ДІЯЛЬНІСТЬ - ЦЕ НАПОВНЮВАТИ ЖИТ- } \\
\text { ТЯМ (die Wirtschaftspartnerschaft unserer beiden Länder mit } \\
\text { Leben erfüllen (Merkel, } 2020 \text { (8)). } \\
\end{array}$ \\
\hline & $\begin{array}{l}\text { Просторові та } \\
\text { часові орієнтири }\end{array}$ & 10,7 & 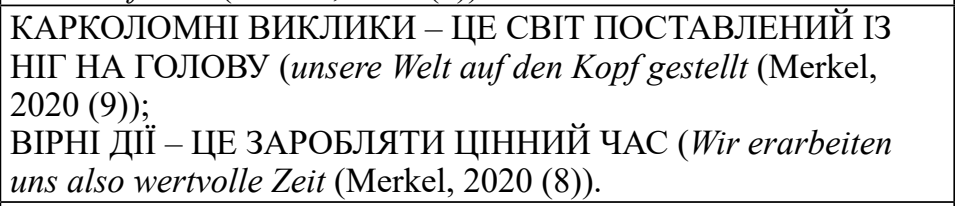 \\
\hline & Дім & 5,4 & $\begin{array}{l}\text { НІМЕЦЬКА ЕКОНОМІКА - ЦЕ НАШ ДІМ (Wir sind heute } \\
\text { hier im Haus der Deutschen Wirtschaft zu Hause; wir sind heute } \\
\text { im Herzen der deutschen Wirtschaftsorganisationen zu Hause } \\
\text { (Merkel, } 2019 \text { (11)). }\end{array}$ \\
\hline \multirow{3}{*}{$\begin{array}{c}\text { СИСТЕМА } \\
\text { ЦІННОСТЕЙ }\end{array}$} & Порушення & 8,6 & $\begin{array}{l}\text { ДІЇ ДЛЯ ПОРЯТУНКУ - ЦЕ ЖОРСТКИЙ НАДРІЗ У ПРАВАХ } \\
\text { НА СВОБОДУ (den härtesten Einschnitt in die Freiheitsrechte ... } \\
\text { darstellen) (Merkel, } 2020 \text { (9)); } \\
\text { ЕФЕКТИВНІСТЬ - ЦЕ ЗАХИСТ ДЕМОКРАТІЇ (eigene Pro- } \\
\text { bleme auf dem Rücken von Dieses Virus ist und bleibt eine demo- } \\
\text { kratische Zumutung (Merkel, } 2020 \text { (8)). }\end{array}$ \\
\hline & Стабілізація & 6,3 & $\begin{array}{l}\text { ВЛАСНА ЕФЕКТИВНА ДІЯЛЬНІСТЬ - ЦЕ ОПОРА СТАБІЛЬ- } \\
\text { НОСТІ (als Stabilitätsanker dienen zu können (Merkel, } 2020 \text { (9)); } \\
\text { НАДІЙНИЙ ПАРТНЕР - ЦЕ ПРИХИЛЬНИК ЗАХІДНИХ } \\
\text { ЦІННОСТЕЙ (Aus einem konstruktiven Gedankenaustausch ein } \\
\text { gewinnbringendes Miteinander zu machen (Merkel, } 2020 \text { (8)). }\end{array}$ \\
\hline & Еталонність & 8,6 & $\begin{array}{l}\text { СЛІДУВАННЯ КУРСУ - ЦЕ ПРАГНЕННЯ ВЕРШИН (... ist } \\
\text { ein Gipfel der EU (Merkel, } 2018 \text { (5)); Beides sind die zwei Seiten } \\
\text { einer Medaille ; ... tragender Pfeiler (Merkel, } 2020 \text { (9)). }\end{array}$ \\
\hline
\end{tabular}

ної сфери, про що свідчить їхнє превалювання, зокрема, у виступі в 2020 р., присвяченому зовнішній політиці та безпеці в рамках головування Німеччини в СС: Wenn Europa sich und seine Werte in der Welt behaupten will und das wollen wir; das müssen wir, gelingt uns das nur, wenn wir sowohl stärker als früher unser Schicksal in die eigene Hand nehmen als auch als verlässlicher Partner der westlichen Werte und Interessengemeinschaft agieren (Merkel, 2020 (9)). Канцлеркою вводиться досить сильна умова (Якщо Європа хоче утвердити себе та свої цінності) як стимул для сприйняття необхідності підтримки іiі програми, що надалі марковано модальністю бажання, потреби та здатності 3 займенниковим повтором ( $і$ ми цьвого хочемо; ми мусимо, ми можемо) та завершується метафорою «візьмемо свою долю у свої руки» як підсумком-закликом.

Подібні метафори становлять суттєвий прошарок, особливо в окресленні власних досягнень, наприклад, in einem ständigen Wettbewerb um die besten Ideen und Innovationen bewegen (перебуваємо в постійному змаганні за найкращі ідеї i інновачіï) та пріоритетах спільної діяльності, наприклад, Wie bekommen wir globale Champions auch in Europa? (Як досягти світової першості в Свроni?) (Merkel, 2020 (8)). Ïх функціонування відбувається на фоні органічного поєднання експліцитних закликів до єднання та спільних дій, маркованих займенниками wir i unser, 3 імпліцитно представленим образом мовця як лідера, здатного досягати та підтримувати високий рівень соціальних благ.

Подібне також спостерігаємо і в випадку 3 часткою метафор, базис яких становить сфера досягнень 5,4\%: Unser Land zeigt sich von seiner besten Seite (Наша крайна показує себе з найкращ̧их сторін) (Merkel, 2020 (7)).

Примітною в контексті цього є метафори зі сфери катаклізмів, труднощів і викликів, кількісні показники використання яких сягають 8,6\%. Це дає змогу стверджувати про вагомість маркованих метафорами тверджень як-от durch diese Zeit kommen (подолаємо ией час); steht an Ihrer Seite (стоїть на вамому боиi); Herkulesaufgabe (занадто складне завдання) (Merkel, 2020 (7)); 
in einer Sackgasse stranden (опинитися у глухому куті) (Merkel, 2020 (8)), насамперед, тому, що вони формують у свідомості слухача низку образів із негативним конотативним забарвленням. У процесі розгортання текстового фрагмента це виконує роль контрастуючого елемента, який протиставляється рішучості канцлерки, іiі здатності виявляти характер лідера за складних обставин. Наприклад, Doch niemand sollte deshalb so naiv sein, zu glauben, die Themen Flucht und Migration könnten gleichsam per Knopfdruck ein für alle Mal, wie es oft heißt, gelöst werden (Але ніхто не повинен бути таким наївним, щоб вірити, що питання біженців та міграції можна вирішити раз і назавжди, як ие часто кажуть, одним натисканням кнопки) (Merkel, 2020 (8)).

Загалом функціонування подібних метафор у висловленнях, де досягнення лідерки не представлені прямо, пропонує вже готову картину - повна одностайність у прийнятті певних політичних кроків. Їхня доцільність не ставиться під сумнів, оскільки в основі знаходиться «я» політика розчинене в колективному. Водночас мовець часто вдається до прийому висунення власного образу за допомогою розташування в ініціальній частині блоку, що так чи інакше асоціюються 3 образом досягнень або пов'язаний з екстатичним захопленням від патріотичних гасел, наприклад: Ich sehe unsere deutsche Ratspräsidentschaft als Chance, Europa als solidarische, handlungsfähige und gestaltende Kraft weiterzuentwickeln, die Verantwortung für Frieden und Sicherheit in der Welt übernimmt (Merkel, 2020 (9)).

Цілком очевидно, що Ich sehe на початку висловлення 3 піднесеним ад'єктивним (solidarische, handlungsfähige, gestaltende) та субстантивним (Kraft, Verantwortung, Sicherheit) оздобленням, що загалом не складно транспонувати в концепт НІМЕЧЧИНА - ТВОРЧА СИЛА РОЗВИТКУ ЄВРОПИ, викликає і закріплює у свідомості слухача прямий асоціативний зв'язок. Разом із тим чим сильніше експліцитно представлена самопрезентаційність, тим більшого акцентного виділення набуває ініціальне фокусування на образі мовця. Розглянемо приклад: Dennoch bin ich zutiefst davon überzeugt, dass die transatlantischen Beziehungen, die Zusammenarbeit und das Bündnis mit den USA und in der NATO ein zentraler, tragender Pfeiler unserer Außen- und Sicherheitspolitik sind und bleiben (Merkel, 2020 (9)). Як бачимо, стрижнем цієї тези є два моменти, які практично врізаються в свідомість - «я глибоко переконана», де прислівник zutiefst збільшує і без того сильну позицію цієї фрази, і метафора «міџна опора намої зовніш- ньої політики», опосередковані відсиланнями до найбільш потужного геополітичного гравця на планеті (Bündnis mit den USA und in der NATO). Також для переконування аудиторії в міцності та силі демократії, канцлерка вдається до ії метафоричного опису як агента самостійних дій (Марченко, Савчук, 2020: 31). Wir spüren in Ihrem Haus den Herzschlag der europäischen Demokratie (Mu відчуваємо сериебиття європейської демократії у вашому домі) (Merkel, 2018 (5)).

Результати аналізу засвідчують, що у випадку зі сферою людини мовцем моделюється картина світу у спосіб, що максимально наближує властиві людським діяльностям поняття, як-от емоційно-чуттєве сприйняття дійсності, життя та смерть, просторові та часові орієнтири, дім, частка яких від загальної кількості проаналізованих прикладів становить 29,8\%. Таким чином, антропоморфні метафори є невід'ємною частиною виступів А. Меркель.

3 метою привернути увагу до гострої проблематики та водночас підкреслити ефективність власної діяльності канцлеркою використовуються метафори в основі яких життя та смерть, наприклад: [...] ihr Leben verloren haben (втратити життя) (Merkel, 2020 (7)). Такі яскраві метафоричні образи слугують потужним мотиваційним фактором і презентації якостей канцлерки, і вербального впливу, що засвідчує досить висока частота 7,4\% їхнього використання. Навіть у межах однієї промови часто спостерігається споріднені приклади таких метафор: <...> die Initiative ins Leben gerufen haben (оживили ініиіативу); <...> die Wirtschaftspartnerschaft unserer beiden Länder mit Leben erfüllen (наповнити життям економічне партнерство) (Merkel, 2020 (8)).

Крім того, невід'ємним атрибутом виступів Ангели Меркель, особливо коли йдеться про особливі проблеми, війни, епідемії, є метафори емоційно-чуттєвого сприйняття людини, наприклад: Dabei behalten wir auch die deutsche und europäische Wirtschaft im Blick (При иьому ми не випускаємо з виду німецьку $і$ європейську економіку) (Merkel, 2020 (8)). За тим самим принципом сюди належать і просторові та часові орієнтири людини: Die Coronavirus-Pandemie hat unsere Welt auf den Kopf gestellt (Пандемія корона вірусу поставила наш світ 3 ніг на голову) (Merkel, 2020 (9)); Wir erarbeiten uns also wertvolle Zeit (Отже, ми зароблясмо для себе цінний час) (Merkel, 2020 (8)). Примітними також $\epsilon$ метафори персоніфікації, якими створюються образи єднання і збільшується сила закликів: <...> unser Schicksal in die eigene Hand nehmen (візьмемо свою долю у власні руки) (Merkel, 2020 (9)). 
У випадку з метафорами, вихідним базисом творення яких є система цінностей, ми розглядаємо дії, спрямовані на їхнє порушення, стабілізацію та еталонність, частка яких становить $23,5 \%$. Аналіз особливостей їхнього функціонування дає змогу стверджувати, що презентація образу політика може конструюватися шляхом ототожнення власної ефективної діяльності А. Меркель зі стабільністю в підтримці та забезпеченні системи цінностей, наприклад, Gerade in einer destabilisierten Welt ist es in unserem europäischen Interesse, als Stabilitätsanker dienen zu können (Merkel, 2020 (9)). Як бачимо, зазначений фрагмент зосереджено на запевненнях підтримки unserem europäischen Interesse, що втілюється поєднанням контрастної пари дестабілізований світ - стабільність. При цьому рух від хаосу нестабільності до упорядкованості як кінцевої мети, яка одночасно імпліцитно презентує образ канцлерки, представлено метафорою Stabilitätsanker dienen zu können (служити якорем стабільності).

Подібну функцію, власне емфатичне виділення тез, покликаних створити певне уявлення про ситуацію та ефективність діяльності мовця в ній, виконують метафори, зосереджені на порушеннях в усталеній системі цінностей. Так, наступний приклад: Noch vor wenigen Wochen schien unvorstellbar, dass nur wenig später freiheitliche Demokratien umfangreiche Maßnahmen wie
Ausgangs- und Kontaktbeschränkungen erlassen müssen, die auch hierzulande den härtesten Einschnitt in die Freiheitsrechte der Bürgerinnen und Bürger seit Gründung der Bundesrepublik Deutschland darstellen (Merkel, 2020 (9)), демонструє ефективність застосування метафори жорстокий надріз у правах на свободу, для поглиблення опису всього трагізму ситуації. Крім того, семантика прикметникових вкраплень ініціальної частини висловлювання (немислимий, ліберальний, масштабні) в поєднанні 3 негативним аксіологічним потенціалом самої метафори, створюють експланаторну тональність, яка, зрештою, дає змогу пом'якшити можливе негативне сприйняття рішень канцлерки.

Висновки. Таким чином, здійснений аналіз дає змогу констатувати, що засобами метафори Ангелою Меркель конструюється і позитивно, i негативно аксіологічні моделі інтерпретації картини світу. При цьому обидві моделі однаково вагомі для формування образу лідера, оскільки вони, насамперед, створюють певне уявлення про ситуацію, в контексті якої підкреслюються здобутки діяльності канцлерки. Найбільш продуктивними метафорами є такі понятійні сфери, як соціум і людина. Саме їхнє функціонування дає змогу описувати заходи для подолання економічних викликів і збільшувати ефективність власної політичної поведінки.

\section{СПИСОК ВИКОРИСТАНИХ ДЖЕРЕЛ}

1. Марченко Н. М., Савчук О. Г. Структурно-семантичні та лінгво-когнітивні особливості німецькомовних парламентських промов канцлери Ангели Меркель. Science und Educaition a New Dimension. Philology, VIII (68), Issue: 226. Budapest, 2020. P. 30-33. URL: https://seanewdim.com/uploads/3/4/5/1/34511564/httpsdoi.org10.31174sendph2020-226viii68-07.pdf.

2. Савчук В. Сутність понять «стратегія», «тактика» та «хід» у розрізі проведення експериментально-фонетичного дослідження англомовного президентського дискурсу. Теоретична $і$ дидактична філологія : збірник наукових праць. Серія «Філологія». Переяслав-Хмельницький: Домбровська Я. М. 2017. Випуск 26. С. 141-151.

3. Тамерьян Т. Ю., Цаголова В. А. Динамика метафорической вербализации образа Kanzlerin Angela Merkel. Вестник Российского университета дружбы народов. Серия : Теория языка. Семиотика. Семантика, 2019. Vol. 10, no. 1, pp. 141-151.

4. Цаголова В. А. Немецкая политическая метафора (на материале описательного дискурса канцлера ФРГ А. Меркель). Актуальные проблемы филологии и педагогической лингвистики. 2014. № 16. URL: https://cyberleninka.ru/ article/n/nemetskaya-politicheskaya-metafora-na-materiale-opisatelnogo-diskursa-kantslera-frg-a-merkel/.

5. Merkel A. Rede von Bundeskanzlerin Merkel vor dem Europäischen Parlament (13 November 2018 in Straßburg). URL: https://www.bundeskanzlerin.de/bkin-de/aktuelles/rede-von-bundeskanzlerin-merkel-vor-dem-europaeischen-parlamentam-13-november-2018-in-strassburg-1549538/.

6. Merkel A. Rede von Bundeskanzlerin Dr. Angela Merkel zum Haushaltsgesetz 2019 vor dem Deutschen Bundestag (21 November 2018). URL: https://www.bundesregierung.de/breg-de/suche/rede-von-bundeskanzlerin-dr-angela-merkel$1553398 /$.

7. Merkel A. Rede von Bundeskanzlerin Dr. Angela Merkel am 3. April 2020 in Berlin. URL: https://www.bundesregierung. de/breg-de/service/bulletin/rede-von-bundeskanzlerin-dr-angela-merkel-1739802/.

8. Merkel A. Rede von Bundeskanzlerin Merkel im Rahmen der deutsch-griechischen Wirtschaftskonferenz am 9. März 2020 in Berlin. URL: https://www.bundeskanzlerin.de/bkin-de/aktuelles/rede-von-bundeskanzlerin-merkel-im-rahmen-derdeutsch-griechischen-wirtschaftskonferenz-am-9-maerz-2020-in-berlin-1729382/.

9. Merkel A. Rede von Bundeskanzlerin Merkel im Rahmen der Veranstaltung „Außen- und Sicherheitspolitik in der deutschen EU-Ratspräsidentschaft“ der Konrad-Adenauer-Stiftung am 27. Mai 2020. URL: https://www.bundeskanzlerin. de/bkin-de/aktuelles/rede-von-bundeskanzlerin-merkel-im-rahmen-der-veranstaltung-aussen-und-sicherheitspolitik-in-derdeutschen-eu-ratspraesidentschaft-der-konrad-adenauer-stiftung-am-27-mai-2020-1755884/. 
10. Merkel A. Rede von Bundeskanzlerin Merkel zur 55. Münchner Sicherheitskonferenz am 16. Februar 2019 in München. URL: https://www.bundeskanzlerin.de/bkin-de/aktuelles/rede-von-bundeskanzlerin-merkel-zur-55-muenchnersicherheitskonferenz-am-16-februar-2019-in-muenchen-1580936/.

11. Merkel A. Rede von Bundeskanzlerin Merkel bei der Konferenz „Compact with Africa“ am 19. November 2019 in Berlin. URL: https:/www.bundeskanzlerin.de/bkin-de/aktuelles/rede-von-bundeskanzlerin-merkel-bei-der-konferenzcompact-with-africa-am-19-november-2019-in-berlin-1694200/.

12. Neubrand A. Frauen in Führungspositionen. Ein Vergleich zwischen Deutschland und Frankreich. Hamburg: Diplomica Verlag GmbH, 2009.

\section{REFERENCES}

1. Marchenko N. M., Savchuk O. H. Strukturno-semantychni ta linhvo-kohnityvni osoblyvosti nimetskomovnykh parlamentskykh promov kantslera Anhely Merkel [Structural-semantic and linguistic-cognitive features of German-speaking parliamentary speeches by Chancellor Angela Merkel]. Science und Educaition a New Dimension. Philology, VIII (68), Issue: 226. Budapest, 2020. pp. 30-33 [in Ukrainian].

2. Savchuk V. Sutnist poniat "stratehiia", "taktyka" ta "khid" u rozrizi provedennia eksperymentalno-fonetychnoho doslidzhennia anhlomovnoho prezydentskoho dyskursu [The essence of the concepts "strategy", "tactic" and "move" for studying presidential discourse in tht context of experimental phonetics]. Theoretical and Didactic Philology. Pereiaslav-Khmelnytskii : Dombrovska Ya. M. 2017, Nr 26. pp. 141-151 [in Ukrainian].

3. Tameryan T. Yu., Cagolova V. A. Dinamika metaforicheskoj verbalizacii obraza Kanzlerin Angela Merkel [Dynamics of metaphorical verbalization of the image of Kanzlerin Angela Merkel]. Vestnik Rossijskogo universiteta druzhby narodov. Series: Theory of language. Semiotics. Semantics, vol. 10, no. 1, 2019. pp. 141-151 [in Russian].

4. Cagolova V. A. Nemeckaya politicheskaya metafora (na materiale opisatelnogo diskursa kanclera FRG A. Merkel) Aktualnye problemy filologii i pedagogicheskoj lingvistiki [German political metaphor (based on the descriptive discourse of German Chancellor A. Merkel) Actual problems of philology and pedagogical linguistics]. 2014. № 16. URL: https:// cyberleninka.ru/article/n/nemetskaya-politicheskaya-metafora-na-materiale-opisatelnogo-diskursa-kantslera-frg-a-merkel/ [in Russian].

5. Merkel A. Rede von Bundeskanzlerin Merkel vor dem Europäischen Parlament (13 November 2018 in Straßburg). URL: https://www.bundeskanzlerin.de/bkin-de/aktuelles/rede-von-bundeskanzlerin-merkel-vor-dem-europaeischen-parlament-am-13-november-2018-in-strassburg-1549538/ [in German].

6. Merkel A. Rede von Bundeskanzlerin Dr. Angela Merkel zum Haushaltsgesetz 2019 vor dem Deutschen Bundestag (21 November 2018). URL: https://www.bundesregierung.de/breg-de/suche/rede-von-bundeskanzlerin-dr-angela-merkel-1553398/ [in German].

7. Merkel A. Rede von Bundeskanzlerin Dr. Angela Merkel am 3. April 2020 in Berlin. URL: https://www.bundesregierung.de/breg-de/service/bulletin/rede-von-bundeskanzlerin-dr-angela-merkel-1739802/ [in German].

8. Merkel A. Rede von Bundeskanzlerin Merkel im Rahmen der deutsch-griechischen Wirtschaftskonferenz am 9. März 2020 in Berlin. URL: https://www.bundeskanzlerin.de/bkin-de/aktuelles/rede-von-bundeskanzlerin-merkel-im-rahmen-der-deutsch-griechischen-wirtschaftskonferenz-am-9-maerz-2020-in-berlin-1729382/ [in German].

9. Merkel A. Rede von Bundeskanzlerin Merkel im Rahmen der Veranstaltung „Außen- und Sicherheitspolitik in der deutschen EU-Ratspräsidentschaft“ der Konrad-Adenauer-Stiftung am 27. Mai 2020. URL: https://www.bundeskanzlerin. de/bkin-de/aktuelles/rede-von-bundeskanzlerin-merkel-im-rahmen-der-veranstaltung-aussen-und-sicherheitspolitik-in-derdeutschen-eu-ratspraesidentschaft-der-konrad-adenauer-stiftung-am-27-mai-2020-1755884/ [in German].

10. Merkel A. Rede von Bundeskanzlerin Merkel zur 55. Münchner Sicherheitskonferenz am 16. Februar 2019 in München. URL: https:/www.bundeskanzlerin.de/bkin-de/aktuelles/rede-von-bundeskanzlerin-merkel-zur-55-muenchnersicherheitskonferenz-am-16-februar-2019-in-muenchen-1580936/ [in German].

11. Merkel A. Rede von Bundeskanzlerin Merkel bei der Konferenz „Compact with Africa“ am 19. November 2019 in Berlin. URL: https://www.bundeskanzlerin.de/bkin-de/aktuelles/rede-von-bundeskanzlerin-merkel-bei-der-konferenz-compact-with-africa-am-19-november-2019-in-berlin-1694200/ [in German].

12. Neubrand A. Frauen in Führungspositionen. Ein Vergleich zwischen Deutschland und Frankreich. Hamburg: Diplomica Verlag GmbH, 2009. [in German]. 